\title{
Central Nervous System Solitary Fibrous Tumor/Hemangiopericytoma
}

National Cancer Institute

\section{Source}

National Cancer Institute. Central Nervous System Solitary Fibrous

Tumor/Hemangiopericytoma. NCI Thesaurus. Code C129526.

A mesenchymal, non-mening othelial neoplasm arising from the central nervous system.

It is characterized by a collagenous and low cellularity spindle cell and/or

hemangiopericytomatous histopathological pattern, recurrent intrachromosomal

rearrang ement on chromosome $12 q$ that results in the fusion of the NAB2 and STAT 6

genes, high recurrence rates, and long-term risk of systemic metastasis. 